\title{
Transcultural adaptation and validation of the Stanford Presenteeism Scale for the evaluation of presenteeism for Brazilian Portuguese
}

\author{
Heloisa Campos Paschoalin ${ }^{1}$ \\ Rosane Harter Griep² \\ Márcia Tereza Luz Lisboa ${ }^{3}$ \\ Diana Corrêa Bandeira de Mello ${ }^{4}$
}

Objective: describe the process of transcultural adaptation and validation of the Stanford Presenteeism Scale for Brazilian Portuguese. Methods: Methodological study of the cultural adaptation and validation of the tool which involved 153 nursing staff and included six aspects of equivalence, obtained through the following stages: translation, first version of consent, retranslation, specialist committee, pre-test, study of test-retest credibleness and dimensional validity. Results: The stability of the items varied from moderate to almost perfect and the sequence constancy was almost perfect. Two factors were identified through the exploratory fact analysis: the first one included the physical aspects - completing work; and the second one the psychological aspects - avoided distraction. Conclusions: the results suggest adequacy of the tool in the Brazilian Portuguese version, indicating its use in the context of the study group and in similar groups, contributing to the study of evidences which consolidate strategies that favor the health conditions of the jobholders.

Descriptors: Reproducibility of Results; Occupational Health Nursing; Occupational Health; Working Conditions.

\footnotetext{
1 Doctoral student, Escola de Enfermagem Anna Nery, Universidade Federal do Rio de Janeiro, Rio de Janeiro, RJ, Brazil. Professor Adjunto, Faculdade de Enfermagem, Universidade Federal de Juiz de Fora, Juiz de Fora, RJ, Brazil.

${ }^{2}$ PhD, Researcher, Instituto Oswaldo Cruz, Fundação Oswaldo Cruz (FIOCRUZ), Rio de Janeiro, RJ, Brazil.

${ }^{3} \mathrm{PhD}$, Associate Professor, Escola de Enfermagem Anna Nery, Universidade Federal do Rio de Janeiro, Rio de Janeiro, RJ, Brazil.

${ }^{4}$ MSc, Colaborative Researcher, Instituto Oswaldo Cruz, Fundação Oswaldo Cruz (FIOCRUZ), Rio de Janeiro, RJ, Brasil. Professor, Universidade Veiga de Almeida, Rio de Janeiro, RJ, Brazil.
}

Corresponding Author:

Heloisa Campos Paschoalin

Universidade Federal de Juiz de Fora. Faculdade de Enfermagem

Rua José Lourenço Kelmer, s/n

Campos Universitário

Bairro: São Pedro

CEP: 36036-900, Juiz de Fora, MG, Brasil

E-mail: hcpaschoalin@gmail.com 


\section{Introduction}

Absenteeism and presenteeism affect in prominent form the work organizations, in definitions which are contradictory $^{(1)}$. While in the first case the employee is absent from work due to illness, the second case is defined through the presence of the individual at work in spite of illness or any physical or psychological problem(1-3). Different to absenteeism, objectively identified and widely investigated ${ }^{(4)}$, the presenteeism is a more recently studied phenomenon and barely noticed, even so being commonly present in the work organizations. It interferes with the productivity and with the performance of the professional, once the individual who keeps working without adequate health conditions cannot comply with the assignments satisfactorily ${ }^{(1-4)}$.

However, beyond the quantity, presenteeism also affects the quality of the assigned work what is reflected in errors and omissions in the tasks ${ }^{(1)}$. Moreover, it is recognized as one of the risk factors for future absenteeism due to illness ${ }^{(2,5)}$, showing that both the absenteeism and the presenteeism are related to the loss of productivity, causing higher costs. In the absenteeism the costs can directly be measured due to a total loss of the productivity, whereas the direct and indirect costs of presenteeism are more difficult to estimate since the loss of productivity occurs during the work, possibly generating an even bigger impact on the organizations $^{(3,6-9)}$.

Facing the magnitude of the problem, several studies have been conducted $(2-3,7,10-11)$, and in the area of the nursing, international studies distinguish the high index of presenteeism and the consequences for the team, the health institution and the patients ${ }^{(8,12-14)}$. The nursing being entirely involved in the human care, it is essential that its staff members are physically and emotionally prepared in order to satisfactorily develop all the responsibilities that are assigned to them. To keep working without physical and psychological conditions can cause the reduction of the concentration capacity and the level of attention, representing serious risks for those who are under their care ${ }^{(8,12-13)}$.

Although the subject being relatively recent, 17 research tools ${ }^{(15)}$ which evaluate the absenteeism and/ or presenteeism and its implications in the context of work and health of the professional have already been described in literature. Among the available tools, the Stanford PresenteeismScale (SPS-6)(16) stands out for exclusively evaluating the presenteeism. This instrument strives to determine the relation between presenteeism, health problems and the productivity among the professionals. It is composed of six items, using a Likert scale, varying from one (I totally disagree) to five (I totally agree); the score obtained by adding up the punctuations of the items can vary from six to thirty. Originally, it was applied by means of selfcompletion where the respondents determined up to which point they agree to the statements which describe how their health condition can or cannot affect their work. The scale measures abilities of the participants to concentrate and execute the work, though having a health problem, by means of two factors: to finish the work and to avoid distraction. The first factor is related to the physical causes and the second one refers to the psychological aspects ${ }^{(16)}$.

It is considered a questionnaire used in the international literature ${ }^{(6,11)}$, seen as a tool of simple application that presents adequate psychometric properties in other studies ${ }^{(6,17)}$. The original scale, elaborated in the English language ${ }^{(16)}$, and the version adapted for Portugal(6,11), present high internal consistency and the factorial analysis of both the studies neglected two dimensions, corroborating the theoretic construction $^{(6)}$ of the existence of two independent factors (accomplished work and avoided distraction).

In view of the importance of the diagnosis of presenteeism in the work organizations and the absence of national tools, the distribution of the adapted tool may contribute with the diagnosis of presenteeism among nursing professionals in the Brazilian context and in the development of strategies which favor the health conditions of these professionals. Therefore, this article has the objective to present the cultural adaptation and validation of the Stanford PresenteeismScale for evaluation of presenteeism to the Brazilian culture.

\section{Methods}

The process of translation and adaptation of the SPS6 followed the proposed script for international(18) and national ${ }^{(19)}$ studies, including six aspects of equivalence: conceptual (it searches the existence of a common concept in the two populations, that one where the scale was developed and that one where it is going to be applied), items (where the concepts are investigated, generally, through questions or items that are corresponding in the two languages), semantic (it involves the transference of the word meanings contained in the original tool to the version), operational (it refers to the format of the tool, measuring methods, form of application), mensuration 
(it refers to the psychometric properties of the tool) and functionary (both tools, original and new version must measure the same concepts in different cultures). The adaptation and use of the scale were authorized by the author of the same one and the study obtained a favorable opinion from the Research Ethics Committee of the University Hospital of the Federal University Juiz De Fora (UFJF) under protocol no. 058/2011. All the citizens that participated in the study had signed the term of free and clarified assent.

The adaptation and validation of the tool followed the following stages:

1 - Translation of the scale: executed by three Brazilian translators, with domain of the English language, in independent form. By means of a meeting with the researcher, each translator received a guide with the instructions for the work to be accomplished, distinguishing the importance of semantic equivalence of the terms, to the detriment of only one literal translation.

A specific tool for self-completion was elaborated for the pertinent translation and comments, requesting that each translator attributed a grade, varying from 0 (no difficulty) to 10 (maximum difficulty) that expressed the degree of difficulty in the translation of each item and reply option.

2 - First version of consent: The three translations were evaluated through a meeting with the researcher and the two people who lead the study. The wording, the use of colloquial language and the equivalence of the sense (semantics) of the questions and answers from the translators were analyzed. Some modifications were made in accordance with the suggestions given by the evaluators and a version was elaborated.

3 - Retranslation: The first version passed in an independent form two professionals who have English as their native language and are fluent in Portuguese for the process of retranslation into English. In the light of the two retranslations, a new meeting with the researcher and the leaders of the study was called to define the retranslated version.

4 - Specialist committee: The original version in English, the version of consent of the translation into Portuguese and the two retranslations into English were compared by a committee of specialists with the objective of developing the version to be used in the pre-test. The committee was composed by two researchers in the area of employee health, an epidemiologist and a researcher graduated in humanities, all with experience in the use of scales and epidemiologic studies on employee health.
In this step, conceptual and semantic equivalences were analyzed in two meetings with an average duration of four hours each and consultations of the author of the scale were made throughout the translation process to resolve doubts and maintain the semantic equivalence.

5 - Pre-test: The version defined by the specialists was submitted to pre-tests with 30 volunteers of another hospital unit with the objective to test the scale regarding the comprehension, the clarity of the questions and answers and encountered difficulties. After a meeting with the volunteers where the objectives of the study were explained, the scale was applied in interview form and at the end, each participant was questioned about the tool in relation to the previously described items. The average application time of the scale was 20 minutes and no doubt or difficulty of comprehension was reported.

6 - The tool was inserted in a multidimensional questionnaire and applied to the set of nursing staff of a university hospital in Juiz de Fora - MG. Of a total of 313 eligible people, 272 (86.9\%) adhered to the methodological study of cultural adaptation and validation of the tool. The dimensional validity was realized from the set of staff who had stated health problems in last the 30 days (153 staff members, corresponding to $56.2 \%$ ).

7 - The study of test-retest credibleness was carried out in a subsample of convenience, composed by 50 (32.7\%) staff members who had reported presenteeism in last the 30 days. These staff members answered the SPS- 6 within 7 to 14 days after the application of the questionnaire.

The questionnaires were applied to five nurses by means of face to face interview. These had been trained and guided regarding the correct form of staff approach, the objectives and the ethical questions of the study. The data collection occurred in the months of August and September 2011, at the workplace during the working period, in accordance with the availability of each staff member.

Evaluation of the temporal stability: This was made using the Intraclass Correlation Coefficient (ICC) for the evaluation of the global score and the Kappa statistic with quadratic balance for the evaluation of the items. The following criteria (20) for the evaluation of the credibleness level were adopted: $<0=$ poor; 0 to $0.20=$ weak; 0.21 to $0.40=$ likely, 0.41 to $0.60=$ moderate; 0.61 to $0.80=$ substantial and 0.81 to $1.00=$ nearly perfect. The Cronbach Alpha coefficient was used to evaluate the internal consistency of the global scale and respective 
dimensions, being that the minimum value of 0.70 was used to consider that the items consistently evaluated the same construct(21).

The capacity of the tool in neglecting the dimensions underlying the original version of the scale were evaluated by means of factorial analysis, applying the method of the principal axles (Principal AxisFactoring) and varimax rotation for the extraction of factors. A minimum factorial extraction of factors of \pm 0.30 was stipulated in the interpretation. The number of factors with intrinsic value (eigenvalue) superior to one and the Cattell'sScreetest determine the number of factors that should be extracted. The Kaiser Meyer-Olkin (KMO) index and the Bartlett sphericity test (BTS) evaluated the adequacy of the items to the procedure of factorial analysis(22). All the analyses were made using the SPSS program (version 18).

\section{Results}

Although the term presenteeism has not been identified in the Brazilian dictionary yet, the concept has been widely used, mainly in the area of the economy and administration. Therefore, the conceptual equivalence in the two languages was accepted.

The level of difficulty attributed by the translators varied from "no difficulty" to "little difficulty". Two expressions which presented some degree of difficulty in the translation: "distracted me from" of the item "My (health problem) distracted me from taking pleasure in my work", and "I felt hopeless" in the item "I felt hopeless about finishing certain work tasks due my (health problem)" hence there is no directly corresponding expression in the Portuguese language. In the consent meeting, new consultations of English and Portuguese dictionaries were made as to determine the best option for those two questions. For the expression "distracted me from" was adopted, in principle, the translation "não me permitiu" and for "I felt hopeless", "Eu me senti desanimado". The first version of consent was evaluated by specialists and compared with the original, then some suggested assimilations were made. The expression " $I$ felt hopeless", was then changed to "Eu me senti sem ânimo".

After the accomplishment of the retranslations into English, a new meeting of consent was called where the retranslations were compared with the translated version with the aim to conclude the final version of the tool. However, some divergences related to the previously mentioned expression "distracted me from" remained and kept causing difficulty in order to find a word that provided semantic equivalence in the scales. Then a consultation of the author of the original scale was made, presenting the doubts and possibilities of translation. Considering his reply, it was settled for the following translation: "Devido ao meu problema de saúde não pude ter prazer no trabalho" for being considered the one that best represents the meaning of the expression in English, being then concluded the final version of the tool, translated into the Portuguese language. The descriptions of the items of the original version and in Brazilian Portuguese are shown in Figure 1.

\begin{tabular}{|c|c|}
\hline Original version & Adapted version \\
\hline $\begin{array}{l}\text { Directions: Please describe your work experiences in the past month. } \\
\text { These experiences may be affected by many environmental as well as } \\
\text { personal factors, and may change from time to time. For each of the } \\
\text { following statements, please check one of the following responses to } \\
\text { show your agreement or disagreement with this statement in describing } \\
\text { your work experiences in the past month. } \\
\text { Please use the following scale: } \\
\ldots \text { I strongly disagree with the statement } \\
\ldots \text { I somewhat disagree with the statement } \\
\ldots \text { I am uncertain about my agreement with the statement } \\
\ldots \text { I somewhat agree with the statement } \\
\ldots \text { I strongly agree with the statement }\end{array}$ & $\begin{array}{l}\text { Por favor, descreva suas experiências no trabalho nos últimos } 30 \text { dias. } \\
\text { Essas experiências podem ter sido influenciadas por diversos fatores } \\
\text { pessoais e do ambiente e alteradas ao longo do tempo. Para cada } \\
\text { afirmativa abaixo, escolha apenas uma única resposta que melhor } \\
\text { retrata seu grau de concordância ou discordância considerando suas } \\
\text { experiências de trabalho nos últimos } 30 \text { dias. } \\
\text { Por favor, utilize a seguinte escala: } \\
\ldots \text { Eu discordo totalmente } \\
\ldots \text { Eu discordo parcialmente } \\
\ldots \text { Não concordo nem discordo } \\
\ldots \text { Eu concordo parcialmente } \\
\ldots \text { Eu concordo totalmente }\end{array}$ \\
\hline $\begin{array}{l}\text { 1-Because of my (health problem)*the stresses of my job were much } \\
\text { harder to handle. }\end{array}$ & $\begin{array}{l}\text { 1- Devido ao meu (problema de saúde)* foi muito mais difícil lidar com } \\
\text { o estresse no meu trabalho. }\end{array}$ \\
\hline $\begin{array}{l}\text { 2- Despite having my (health, problem) }{ }^{\star} \text {, I was able to finish hard tasks } \\
\text { in my work. }\end{array}$ & $\begin{array}{l}\text { 2- Apesar do meu (problema de saúde) }{ }^{*} \text {, consegui terminar tarefas } \\
\text { difíceis no meu trabalho }{ }^{\dagger} \text {. }\end{array}$ \\
\hline 3- My (health problem)* distracted me from taking pleasure in my work. & $\begin{array}{l}\text { 3- Devido ao meu (problema de saúde) }{ }^{*} \text {, não pude ter prazer no } \\
\text { trabalho. }\end{array}$ \\
\hline $\begin{array}{l}\text { 4- I felt hopeless about finishing certain work tasks, due to my (health } \\
\text { problem)*. }\end{array}$ & $\begin{array}{l}4 \text { - Eu me senti sem ânimo para terminar algumas tarefas no trabalho, } \\
\text { devido ao meu (problema de saúde)*. }\end{array}$ \\
\hline
\end{tabular}




\begin{tabular}{|l|l|}
\hline \multicolumn{1}{|c|}{ Original version } & \multicolumn{1}{|c|}{ Adapted version } \\
\hline $\begin{array}{l}\text { 5- At work, I was able to focus on achieving my goals despite my (health } \\
\text { problem)*. }\end{array}$ & $\begin{array}{l}\text { 5- No trabalho consegui me concentrar nas minhas metas apesar do } \\
\text { meu (problema de saúde) }\end{array}$ \\
\hline $\begin{array}{l}\text { 6- Despite having my (health problem)* } \\
\text { complete all my work. }\end{array}$ & $\begin{array}{l}\text { 6- Apesar do meu (problema de saúde) } \\
\text { todo o meu trabalho energia para terminar }\end{array}$ \\
\hline $\begin{array}{l}\text { * Note: the words 'back pain', 'cardiovascular problem', illness, 'stomach to } \\
\text { problem', or other similar descriptors can be substituted for the words } \\
\text { 'health problem', in any of these items. }\end{array}$ & $\begin{array}{l}\text { * Nota: as expressões "dor nas costas", "problema cardiovascular", } \\
\text { "doença","problema de estômago" e outros termos semelhantes } \\
\text { podem ser substituídos pela palavra "problema de saúde" em qualquer } \\
\text { um desses itens. }\end{array}$ \\
\hline
\end{tabular}

The Stanford PresenteeismScale (SPS-6; 2001 version) is jointly owned by Merck \& Co. Inc. and Stanford University School of Medicine. tItems which must have reverted punctuation before the addition of the global score sum.

Figure 1 - Original and adapted versions from the Stanford PresenteeismScale (SPS-6)

The subsample which was part of the test-retest credibleness study presented, in general, similar characteristics to the staff members present in the sectional study, even so it could be observed among them a bigger ratio of nurses and minor ratio of daytime staff (Table 1 ).
The score averages of each item of the SPS- 6 were similar in the test and the retest. The balanced Kappa of the scale items varied from 0.61 to 0.94 and the global scale presented an intra-class correlation coefficient of 0.91 (Table 2).

Table 1 - Description of the present participants of the sectional study and the test-retest credibleness study, Juiz de Fora, MG, Brazil, 2011

\begin{tabular}{|c|c|c|}
\hline \multirow{3}{*}{ Variables } & Attendees sectional study & \multirow{2}{*}{ Test-retest credibleness study $n=50$} \\
\hline & $n=153$ & \\
\hline & n (\%) & n (\%) \\
\hline \multicolumn{3}{|l|}{ Gender } \\
\hline Feminine & $122(79.7)$ & $40(80.0)$ \\
\hline Masculine & $31(20.3)$ & $10(20.0)$ \\
\hline Age (years) Average (DP) & $39.8(10.8)$ & $40,0(10.4)$ \\
\hline Age group & 20 to 65 years & 20 to 60 years \\
\hline \multicolumn{3}{|l|}{ Professional category } \\
\hline Nurses & $34(22.2)$ & $13(26.0)$ \\
\hline Admin/supporting staff & $119(77.8)$ & $37(74.0)$ \\
\hline \multicolumn{3}{|l|}{ Shift } \\
\hline Day & $112(73.2)$ & $25(50.0)$ \\
\hline Night & $41(26.8)$ & $25(50.0)$ \\
\hline \multicolumn{3}{|l|}{ Working bond } \\
\hline Civil servants & $91(59.5)$ & $30(60.0)$ \\
\hline Contracted staff & $62(40.5)$ & $20(40.0)$ \\
\hline
\end{tabular}

Table 2 - Stability test-retest of the items which compose the SPS- $6(n=50)$

\begin{tabular}{|c|c|c|c|c|}
\hline Items & $\begin{array}{c}\text { Average (DP) } \\
\text { test }\end{array}$ & $\begin{array}{c}\text { Average (DP) } \\
\text { retest }\end{array}$ & Kappa balance & IC (95\%) \\
\hline 1- Difficult to bear the stress at work & $4.22(1.05)$ & $4.16(1.13)$ & 0.84 & $0.66-100$ \\
\hline 2- Could conclude difficult tasks & $4.48(0.99)$ & $4.54(0.93)$ & 0.86 & $0.65-1.00$ \\
\hline 3- Cannot feel pleasure at work & $3.72(1.34)$ & $3.56(1.34)$ & 0.84 & $0.66-1.00$ \\
\hline 4- Demotivated to conclude tasks & $3.92(1.34)$ & $3.92(1.27)$ & 0.67 & $0.36-0.97$ \\
\hline 5- Could focus on the goals & $4.20(1.14)$ & $4.18(1.08)$ & 0.61 & $0.28-0.94$ \\
\hline 6- Had energy to conclude all the work & $3.98(1.27)$ & $3.88(1.27)$ & 0.94 & $0.88-1.00$ \\
\hline Global scale & $24.52(3.56)$ & $24.24(3.36)$ & $\mathrm{ICC}=0.91$ & $(0.85-0.95)$ \\
\hline
\end{tabular}

The Bartlett sphericity test rejected the null hypothesis that the data correlation matrix was an identity matrix $(p<0.001)$ and the KMO test was equal to 0.674 . These results indicate that there was a relative adequacy of the data matrix to the factorial analysis. 
In accordance with the procedures of the factorial analysis, the model with two factors (dimensions) presented adequate adjustments. The intrinsic values of the two factors were equal to 2.494 and 1.440, respectively, and the variance ratio per item was estimated at $41.56 \%$ and $24 \%$, respectively. Therefore, these two factors explained, as entirety, $65.6 \%$ of the variance found in the data. After the varimax rotation for the stress factors, three items had higher strains in factor I and three in factor II. The first factor enclosed all the items related to the physical aspects and the second one the psychological aspects which involve the presenteeism, being that the correlation between them was 0.312 (Table 3).

Table 3 - Factorial structure of Scale SPS- 6 by means of the exploratory factorial analysis and internal consistency in the dimensions $(n=153)$

\begin{tabular}{lcc}
\hline \multicolumn{1}{c}{ Items } & Factor 1 (physical) & Factor 2 (psychological) \\
\hline 1- Difficult to bear the stress at work & -0.038 & 0.720 \\
2- Could conclude difficult tasks & 0.519 & -0.026 \\
3- Cannot feel pleasure at work & -0.052 & 0.610 \\
4- Demotivated to conclude tasks & 0.269 \\
5- Could focus on the goals & 0.584 \\
6- Had energy to conclude all the work & 0.952 \\
Eigenvalues & 2.494 \\
\% of the explained variance & 41.6 & 0.271 \\
Cronbach Alpha & 0.72 \\
\hline
\end{tabular}

Extraction method: principal components; rotation method: varimax with Kaiser Normalization

\section{Discussion}

This study presents the stages of the transcultural adaptation and validation for the Brazilian Portuguese of a tool for presenteeism evaluation in the work environment. Each stage of the tool adaptation process was executed with utmost care. Nevertheless, successive alterations were necessary based on discussions between researchers, specialists and text revisors, with the objective of getting a conceptual, semantic and operational equivalence. Moreover, it was also strived for presenting results of the mensuration equivalence.

Although the word presenteeism has no definition in the dictionaries of the Portuguese language, the subject has been used in scientific research, therefore being considered equivalent in the two languages.

A high frequency of nursing professionals was identified who referred to working in spite of having health problems. These results corroborate international studies $^{(2,7-8,12-13)}$ and a national study ${ }^{(23)}$ that had identified nursing professionals as part of a category with raised presenteeism indices. The commitment degree that the nursing professionals have with the patients leads them to prevent absence at work, what could justify the high presenteeism indices in this profession ${ }^{(24)}$. Moreover, the long working hours and the high level of physical stress can influence the health of these professionals, affecting directly their productivity ${ }^{(24)}$. The competitiveness in the job market, the reduced number of nursing professionals, mainly in the hospital institutions can, in the same way, favor the occurrence of presenteeism in nursing ${ }^{(8)}$.

The temporal stability of the items, evaluated by means of the Kappa statistics varied from moderate to almost perfect and the intraclass correlation coefficient showed almost perfect credibleness. However, no previous study was identified that could allow us to compare these results.

The internal consistency of the two identified dimensions presented superior values to the adopted minimum criterion (0.70), therefore presenting adequate internal consistency in factor 1 , which integrates the physical aspects related to presenteeism and in factor 2 , related to the psychological aspects. These factors, in accordance with the authors of the tool, form two distinct dimensions: "completing work" and "avoided distraction", respectively. Similar results had been identified in the study that adapted the tool in Portugal(6).

The results of the dimensional analysis in two factors, "completing work" and "avoided distraction", as well as the identified factorial stress match in accordance with the ones presented in the original version in English(16) and the version of Portugal(6).

Some limitations must be taken into account in the evaluation of the presented results. The realized study with a specific group of professionals does not contemplate the peculiarities which could be present in 
other occupations, mainly in those not related to the health area. Moreover, the reduced size of the sample compromises the precision of the estimations and did not allow exploring the credibleness according to subgroups related to age, sex and schooling.

Furthermore, interviews which were applied in the work environment can influence the reliability of the answers of the participants and the application time of the questionnaire; even so we strive for minimizing possible biases through applying interviews in reserved places and with previously scheduled appointments. Another aspect that deserves reflection concerning the influence on the results refers to the functionality via face to face interviews, different to the approach of the original study. Therefore, the accomplishment of other studies is suggested as to construct to a set of evidences concerning the use of the SPS- 6 in studies of associations with different health expositions and results, related to the work procedure in the Brazilian context and in international comparisons.

The absenteeism is recognized as important problem which reflects the health conditions of the nursing team ${ }^{(25)}$ and the evaluation of presenteeism will allow to complement the understanding of the complex net of involved causality in the phenomenon of frail health of the nursing professionals.

\section{Conclusions}

For being a specific tool to evaluate presenteeism, different to other tools described in literature, the SPS6 makes it possible to measure the influence of health problems on the quality of work and the performance of the professional. It demonstrates being a tool of easy understanding, favoring the completion and analysis.

The strict care applied throughout all the stages of the SPS- 6 adaptation allows us to state that the SPS6 presented adequate and comparable psychometric properties to the international studies, indicating its application in future studies of mensuration and investigation of presenteeism among nursing staff and populations with similar characteristics.

\section{References}

1. Hemp P. Presenteeism: at work- but out of it. Harvard Business Rev. 2004;82:49-58.

2. Aronson G, Gustafsson K. Sickness Presenteeism: prevalence, attendance-pressure factors, and an outline of a model for research. J Occup Environ Med. 2005;47(9):959-66.
3. Böckerman P, Laukkanen E. Presenteeism in Finland: determinants by gender and the sector of economy. Ege Akademik Bakis/ Ege Academic Rev. 2009;99(3):1007-16. 4. Johns G. Presenteeism in the workplace: a review and research agenda. J Org Behav. 2010;31:519-42.

5. Bergström G, Bodin L, Hagberg J, Aronson G, Josephson, M. Sickness presenteeism today, sickness absenteeism tomorrow? A prospective study on sickness presenteeism and future sickness absenteeism. J Occup Environ Med. 2009;51:629-38.

6. Ferreira, AJ; Martinez, LF; Sousa, LM; Cunha, JV. Tradução e validação para a língua portuguesa das escalas de presenteísmo WLQ-8 e SPS-6. Avaliação Psicol. 2010;9(2):253-66.

7. Middaugh DJ. Presenteeism: Sick and tired at work. Dermatol Nurs. 2007;1(2):172-85.

8. Pilette PC. Presenteeism in nursing: a clear and present danger to productivity. J Nurs Adm. 2005;35(6):300-3. 9. Rojas R. Enfoque Del presentismo em Empresas de Salud. Ciênc Trabajo. 2007;9(24):64-8.

10. Hansen CD, Andersen JH. Going ill to work - what personal circumstances, attitudes and work-related factors are associated with sickness presenteeism? Soc Sci Med. 2008;67:956-64.

11. Martinez LF. A esperança é a última a morrer? Capital psicológico positivo e presentismo. Comportamento Organizacional e Gestão. 2007;13(1):37-54.

12. Goetzel RZ, Long SR; Ozminkowski, RJ, Hawkins K, Wang S, Lynch W. Health, absence, disability, and presenteeism cost estimates of certain physical and mental health conditions affecting U.S. employers. J Occup Environ Med. 2004;46:398-412.

13. Letvak S, Buck R. Factors Influencing Work Productivity and Intent to Stay in Nursing. Nurs Econom. 2008;26(3):159-65.

14. Letvak S, Rhum CJ. The impact of worker health on long term care: implications for nursing managers. Geriatr Nurs. 2010;31(3):165-9.

15. Mattke S, Balakrishnan A, Bergamo G, Newberry SJ. A review of methods to measure health-related productivity loss. Am J Manage Care. 2007;13(4):211-7.

16. Koopman C; Pelletier KR, Murray JF, Sharda CE, Berger ML, Turpin RS, Hackleman $\mathrm{P}$, Gibson $\mathrm{P}$, Holmes DM, Bendel T. Stanford Presenteeism Scale: health status and employee productivity. J Occup Environ Med. 2002;44(1):14-20.

17. Turpin RS, Ominkowski R, Sharda CE, Collins, JJ, Berger ML, Bilotti GM, Baase CM, Olson MJ, Nicholson S. Reliability and validity of the Stanford Presenteeism Scale. J Occcup Environ Med. 2004:1123-33. 
18. Herdman M, Fox-Rushby, Badia X. A modelo of equivalence in the cultural adaptation of HRQol instruments: the universalist approach. Qual Life Res. 1998; 7:323-35

19. Reichenheim ME, Moraes CL. Operacionalização de adaptação transcultural de instrumentos de aferição usados em epidemiologia. Rev Saúde Pública. 2007;41(4):665-73.

20. Landis JR, Koch GG. The measurement of observer agreement for categorical data. Biometrics 1977;33:159-74.

21. Rowland D, Arkkelin D, Crisler L. Computer-based data analysis: using SPSS in the social and Behavioral Sciences. Chicago Nelson-Hall; 1991.

22. Norman GR, Streiner DL. Biostatistics: the bare essentials. 2nd ed. London: B. C. Decker; 2000. 231 p. 23. Umann J, Guido LA, Grazziano ES. Presenteísmo entre enfermeiros hospitalares. Rev. Latino-Am. Enfermagem. 2012;20(1):159-66.

24. Flores-Sandi G. "Presentismo": Potencialidad en accidentes de salud. Acta Méd Costarric. 2006;48(1):30-4. 25. Junkes MB, Pessoa VF. Gasto financeiro ocasionado pelos atestados médicos de profissionais da saúde em hospitais públicos no estado de Rondônia, Brasil. Rev. Latino-Am. Enfermagem. 2010;88(3):406-12. 